\title{
Antinociceptive and Anthelmintic Activities of Leaves of Leea aequata
}

\author{
Sushanta Halder, Nazmus Saqueeb and Nazmul Qais
}

Department of Clinical Pharmacy and Pharmacology, Faculty of Pharmacy, University of Dhaka Dhaka -1000, Bangladesh

(Received: September 26, 2018; Accepted: November 28, 2018; Published (web): December 10, 2018)

\begin{abstract}
The objective of the study was to evaluate the antinociceptive and anthelmintic activities of the crude methanol extract of leaves of Leea aequata and its fractions. The crude extract and its fractions at 200- and 400-mg/kg bw were subjected to assay for their antinociceptive activity using acetic acid induced writhing and radiant heat tail flicking methods. The ethyl acetate soluble fraction at $400 \mathrm{mg} / \mathrm{kg}$ bw induced $40.97 \%$ inhibition of writhing in mice while the carbon tetrachloride and chloroform soluble fractions of crude extract at the same dose displayed activity with $40.28 \%$ inhibition of writhing as compared to standard diclofenac sodium. The crude extract elongated the reaction time by $57.04 \%$ after 30 minute of administration in radiant heat tail flicking method, which suggested the central antinociceptive activity as compared to morphine. The methanol extract of the leaves of $L$. aequata exhibited profound anthelmintic activity in a dose dependent manner with shortest time of paralysis and death at $100 \mathrm{mg} / \mathrm{ml}$ concentration. It caused paralysis of the earthworm Pheretima posthuma at 9.44 min and death at 12.9 min when compared to the standard drug albendazole, which at $10 \mathrm{mg} / \mathrm{ml}$ concentration revealed the same at 8.21 minutes and 11.18 minutes, respectively.
\end{abstract}

Key words: L. aequata, antinociceptive, anthelmintic, writhing.

\section{INTRODUCTION}

L. aequata is a shrub, 1.2-3.0 $\mathrm{m}$ high belonging to the family Leeaceae. It is widely distributed in India, Myanmar, Malay and Indonesia. In Bangladesh, it is found in the forest areas of Sundarban, Chittagong, Sylhet, Cox's Bazar, Rangamati and Bandarban. This plant is used in the treatment of carbuncle, gastric tumor, hydocele, rheumatism, ureterolithiasis, vertigo, vomiting, bronchitis, dyspepsia, itching, leprosy and tuberculous ulcers. ${ }^{1,2}$ Pain is a subjective experience that results from transfer of and brain analysis of various information such as the nature, location, intensity and duration of a stimulus. It also involves adaptation and modulation of the nociceptive messages by various neuromediators and related

Correspondence to: Nazmul Qais

E-mail: <nqais@du.ac.bd>; Cell: +8801714417750

Dhaka Univ. J. Pharm. Sci. 17(2): 251-255, 2018 (December) DOI: http://dx.doi.org/10.3329/dujps.v17i2.39183 receptors. ${ }^{3}$ Due to the adverse side effects like gastric lesion caused by NSAIDs and tolerance and dependence induced by opiates, the use of these drugs as analgesic agents have not been successful in all the cases. So, analgesic drugs are being searched all over the world as alternatives to NSAIDs and opiates. Anthelmintics are drugs that expel parasitic worms (helminthes) from the body, by either stunning or killing them. ${ }^{4}$ Traditional system of medicine reports the efficacy of several natural plants in eliminating worms. ${ }^{5}$ According to the previous pharmacological studies, antibacterial activity was found in the seeds, stems and roots of L. aequata. ${ }^{6}$ In view of this, an attempt has been made to study the anthelmintic activity of traditional medicinal plants. The purpose of this study was to evaluate the antinociceptic and anthelmintic activities of methanol extract, of leevs of $L$. aequata aval its pet ether and ethyl acetate fractions of the leaves of $L$. aequata. 


\section{MATERIALS AND METHODS}

Plant materials. The leaves of Leea aequata were collected from Sylhet area in March, 2015. A voucher specimen has been deposited in Bangladesh National Herbarium, Dhaka and the accession number found was DACB 41632. After proper washing, the leaves and bark were sun dried for several days. The dried plant was then grounded to coarse powder using high capacity grinding machine.

Preparation of the extract. The powdered material (500 gm) was taken in a clean, amber colored bottle (5 liters) and soaked in 3 liters of methanol. The container with its content was kept for 15 days accompanying occasional shaking and stirring. The whole mixture was then filtered through fresh cotton plug and finally with a Whatman number 1 filter papers. The volume of the filtrate was then reduced using a Buchii rotavapour at low temperature and pressure. The weight of the crude extract was 53 gm. Solvent-solvent partitioning was done using the protocol designed by Kupchan and modified by Van Wagenen et al. (1993). ${ }^{7}$ The crude extract (5 gm) was dissolved in $10 \%$ aqueous methanol. It was extracted with petroleum ether, then with carbon tetrachloride and finally with chloroform. This process was repeated for several times. All the four fractions obtained were evaporated to dryness and were used for further analysis.

Drugs and chemicals. All chemicals and drugs were obtained commercially and were of analytical grade. Methanol, petroleum ether, carbon tetrachloride, chloroform, ethyl acetate, dimethyl formamide, acetic acid and Tween-80 (Merck, Germany) were purchased from the local markets of Dhaka city, Bangladesh. Albendazole, diclofenac sodium and morphine were collected from Beximco Pharmaceuticals Ltd. and Gonoshasthaya Pharmaceuticals Ltd, Bangladesh, respectively.

Animals. Swiss albino mice weighing 25-30 grams were obtained from the Animal Resources Branch of the International Centre for Diarrheal Diseases and Research, Bangladesh (Icddr,b). They were housed in standard polypropylene cages and kept under controlled room temperature $\left(24 \pm 2^{\circ} \mathrm{C}\right.$; relative humidity 60-70\%) in a 12 hrs light-dark cycle in the Animal House of the Institute of Nutrition and Food Science (INFS), University of Dhaka.

Evaluation of antinociceptic activity. The antinociceptive activity was evaluated by acetic acid induced writhing method in mice and hot plate tests. ${ }^{8-}$

${ }^{10}$ Sixty experimental animals were randomly selected and divided into twelve groups. Then mice of each group were fed with vehicle (Tween-80 1\%), diclofenac sodium $(50 \mathrm{mg} / \mathrm{kg} \mathrm{bw})$ and the extracts (400-and $200-\mathrm{mg} / \mathrm{kg} \mathrm{bw})$. After 30 minutes, acetic acid induced writhing response was counted for 15 minutes.

In central antinociceptic activity (hot plate test), mice of each group were treated with vehicle (Tween-80 1\%), morphine (2 mg/kg bw) and the extract (400-and $200-\mathrm{mg} / \mathrm{kg}$ bw). Then, the tail flicking time was tested after 30, 60 and 90 minutes.

Evaluation of anthelmintic activity. The anthelmintic assay was carried as per published method with minor modifications. ${ }^{11}$ The methanol extract of the $L$. aequata leaves were investigated for the anthelmintic activity against Pheretima posthuma. The time taken by worms for paralysis and followed by death of worms were recorded and compared with reference standard albendazole while normal saline water was used as control.

Statistical analysis. All values were expressed as the mean \pm standard error of the mean (SEM) and the result were analyzed statistically by one way analysis of variance (ANOVA) followed by Dunnett's test by using SPSS ver.19. Here, $p<0.05$ was considered to be statistically significant.

\section{RESULTS AND DISCUSSION}

In peripheral antinociceptic activity test (Table 1) the crude methanol extract and its ethyl acetate, chloroform and petroleum ether soluble fractions at $400 \mathrm{mg} / \mathrm{kg}$ bw showed significant antinociceptive activity having $39.58,40.97,40.28$ and $40.28 \%$ of writhing inhibition, respectively as compared to the standard diclofenac $(43.75 \%)$. The result was statistically significant $(\mathrm{p}<0.01)$. 
Peritoneal administration of acetic acid (0.7\%) causes localized inflammation in mice. Following inflammation, there is biogenesis of prostaglandins (from cyclooxygenase pathway) and leukotrienes (lipooxygenase pathway). The released prostaglandins, mainly prostacyclin (PGI2) and to lesser extent prostaglandin-E have been held responsible for pain sensation. Therefore, the results of the acetic acid induced writhing strongly suggests that the mechanism of the extract may be linked partly to the inhibition of lipooxygenase and/or cyclooxygenase in the peripheral tissue, thereby reducing PGE2.

Table 1. Peripheral antinociceptive activity of methanolic crude extract and its different fractions of L. aequata leaves.

\begin{tabular}{|c|c|c|}
\hline Group & $\begin{array}{l}\text { Number of writhing } \\
(\text { Mean } \pm \text { SEM })\end{array}$ & $\begin{array}{c}\% \text { Inhibition of } \\
\text { writhing }\end{array}$ \\
\hline $\begin{array}{l}\text { Control (Tween } 80) \\
\text { (10 mg /kg body weight) }\end{array}$ & $28.8 \pm 1.28$ & - \\
\hline $\begin{array}{l}\text { Standard (Diclofenae) } \\
\text { (50 mg /kg body weight) }\end{array}$ & $16.2 \pm 0.86^{* *}$ & 43.75 \\
\hline $\begin{array}{l}\text { Me (Crude) extract } \\
\text { ( } 200 \mathrm{mg} / \mathrm{kg} \text { body weight) }\end{array}$ & $23.4 \pm 1.4^{*}$ & 18.75 \\
\hline $\begin{array}{l}\text { Me (Crude) extract } \\
\text { (400 mg /kg body weight) }\end{array}$ & $22.6 \pm 1.12 *$ & 21.53 \\
\hline $\begin{array}{l}\text { PE fraction } \\
\text { (200 mg /kg body weight) }\end{array}$ & $22.8 \pm 1.56^{*}$ & 20.83 \\
\hline $\begin{array}{l}\text { PE fraction } \\
\text { (400 mg } / \mathrm{kg} \text { body weight) }\end{array}$ & $17.4 \pm 1.12^{* *}$ & 39.58 \\
\hline $\begin{array}{l}\text { EA fraction } \\
\text { (200 mg /kg body weight) }\end{array}$ & $21 \pm 1.05^{* *}$ & 27.08 \\
\hline $\begin{array}{l}\text { EA fraction } \\
\text { (400 mg } / \mathrm{kg} \text { body weight) }\end{array}$ & $17 \pm 1.1 * *$ & 40.97 \\
\hline $\begin{array}{l}\mathrm{Cl} \text { fraction } \\
\text { (200 mg /kg body weight) }\end{array}$ & $19 \pm 1 * *$ & 34.03 \\
\hline $\begin{array}{l}\mathrm{Cl} \text { fraction } \\
\text { (400 mg /kg body weight) }\end{array}$ & $17.2 \pm 0.74 * *$ & 40.28 \\
\hline $\begin{array}{l}\text { Ct fraction } \\
\text { ( } 200 \mathrm{mg} / \mathrm{kg} \text { body weight })\end{array}$ & $19.8 \pm 0.74 * *$ & 31.25 \\
\hline $\begin{array}{l}\text { Ct fraction } \\
\text { ( } 400 \mathrm{mg} / \mathrm{kg} \text { body weight) }\end{array}$ & $17.2 \pm 0.74 * *$ & 40.28 \\
\hline
\end{tabular}

Note: Each value represents the Mean \pm SEM, $(n=5)$. ** $\mathrm{p}<0.05, * \mathrm{p}<0.01$ compared with control (One- way ANOVA followed by Dunnett's test). $\mathrm{Me}=$ Methanol, $\mathrm{PE}=\mathrm{Petroleum}$ ether, $\mathrm{EA}=\mathrm{E}$ thyl acetate, $\mathrm{Cl}=\mathrm{Chl}$ oroform, $\mathrm{Ct}=$ Carbon tetrachloride.

In central antinociceptic activity test, the tail flicking time was tested after 30, 60 and 90 minutes. The time required for tail flicking of each mouse was recorded and the average flicking time of each group was calculated. The $\%$ time elongation of tail flicking was calculated in respect to the control. The higher the elongation percentage of the group the greater is the groups' central analgesic activity. The central analgesic activity of the test samples were compared in respect to morphine. The extract and fractions effectively elongated the reaction time in a dose dependent manner (Table 2). The methanol extract (200- and $400-\mathrm{mg} / \mathrm{kg} \mathrm{bw}$ ) of $L$. aequata showed significant analgesic activity having $49.83 \%(\mathrm{p}<$ $0.001)$ and $57.04 \%(\mathrm{p}<0.001)$ elongation of reaction time, respectively after 30 minutes of administration of sample compared to the standard morphine $152.45 \%(\mathrm{p}<0.001)$ whereas ethyl acetate fraction 
showed least elongation of reaction time $18.36 \%$. The results were found statistically significant.

The tail flicking method measures the complex response to a non-inflammatory, acute nociceptive input and is one of the models normally used for studying central nociceptive activity. In the tail flick model, reaction time was increased significantly for the test samples and standard drug when compared to the predrug reaction time (control group) at 30 minutes after drug administration and thus it appears that the test sample predominantly inhibits the central pain mechanism.

Table 2. Central antinociceptive activity of methanolic crude extract and its different fractions of $L$. aequata leaves.

\begin{tabular}{|c|c|c|c|}
\hline \multirow[t]{2}{*}{ Group } & \multicolumn{3}{|c|}{ Reaction time (sec) } \\
\hline & $30 \min (\%$ elongation) & $60 \min (\%$ elongation) & $0 \min (\%$ elongation $)$ \\
\hline Control (Tween 80) & $6.1 \pm 0.15$ & $6.22 \pm 0.2$ & $6.36 \pm 0.16$ \\
\hline $\begin{array}{l}\text { Morphine } \\
\text { ( } 2 \mathrm{mg} / \mathrm{kg} \text { body weight })\end{array}$ & $\begin{array}{l}15.4 \pm 0.42 * * * \\
\quad(152.45)\end{array}$ & $\begin{array}{l}13.74 \pm 0.36^{* * * *} \\
\quad(120.90)\end{array}$ & $\begin{array}{l}13.52 \pm 0.36^{* * * *} \\
\quad(112.57)\end{array}$ \\
\hline $\begin{array}{l}\text { Me (Crude) extract } \\
\text { ( } 200 \mathrm{mg} / \mathrm{kg} \text { body weight) }\end{array}$ & $\begin{array}{c}9.14 \pm 0.17 * * * \\
(49.83)\end{array}$ & $\begin{array}{c}8.92 \pm 0.17 * * * \\
(43.40)\end{array}$ & $\begin{array}{c}8.76 \pm 0.15^{* * * *} \\
(37.73)\end{array}$ \\
\hline $\begin{array}{l}\text { Me (Crude) extract } \\
\text { (400 mg/kg body weight) }\end{array}$ & $\begin{array}{c}9.58 \pm 0.25 * * * \\
(57.04)\end{array}$ & $\begin{array}{c}9.22 \pm 0.17 * * * \\
(48.23)\end{array}$ & $\begin{array}{c}9.14 \pm 0.18^{* * *} \\
(43.71)\end{array}$ \\
\hline $\begin{array}{l}\text { PE fraction } \\
\text { ( } 200 \mathrm{mg} / \mathrm{kg} \text { body weight) }\end{array}$ & $\begin{array}{c}7.32 \pm 0.09 * * * \\
(20)\end{array}$ & $\begin{array}{c}7.28 \pm 0.09 * * * \\
(17.04)\end{array}$ & $\begin{array}{c}7.28 \pm 0.07 * * \\
(14.46)\end{array}$ \\
\hline $\begin{array}{l}\text { PE fraction } \\
(400 \mathrm{mg} / \mathrm{kg} \text { body weight })\end{array}$ & $\begin{array}{c}7.86 \pm 0.1 * * * \\
(28.85)\end{array}$ & $\begin{array}{c}7.66 \pm 0.09 * * * \\
(23.15)\end{array}$ & $\begin{array}{c}7.52 \pm 0.1 * * * \\
(18.23)\end{array}$ \\
\hline $\begin{array}{l}\text { EA fraction } \\
\text { ( } 200 \mathrm{mg} / \mathrm{kg} \text { body weight })\end{array}$ & $\begin{array}{l}7.22 \pm 0.1 * * \\
\quad(18.36)\end{array}$ & $\begin{array}{c}7.08 \pm 0.06^{* * *} \\
(13.82)\end{array}$ & $\begin{array}{c}6.96 \pm 0.05^{*} \\
(9.43)\end{array}$ \\
\hline $\begin{array}{l}\text { EA fraction } \\
\text { ( } 400 \mathrm{mg} / \mathrm{kg} \text { body weight) }\end{array}$ & $\begin{array}{c}7.46 \pm 0.12 * * * \\
(22.29)\end{array}$ & $\begin{array}{c}7.24 \pm 0.08 * * * \\
(16.39)\end{array}$ & $\begin{array}{l}7.02 \pm 0.07^{*} \\
(10.37)\end{array}$ \\
\hline $\begin{array}{l}\mathrm{Cl} \text { fraction } \\
(200 \mathrm{mg} / \mathrm{kg} \text { body weight })\end{array}$ & $\begin{array}{c}7.9 \pm 0.08 * * * \\
(29.50)\end{array}$ & $\begin{array}{c}7.72 \pm 0.07 * * * \\
(24.11)\end{array}$ & $\begin{array}{c}7.5 \pm 0.07 * * * \\
(17.92)\end{array}$ \\
\hline $\begin{array}{l}\mathrm{Cl} \text { fraction } \\
(400 \mathrm{mg} / \mathrm{kg} \text { body weight })\end{array}$ & $\begin{array}{c}7.96 \pm 0.14 * * * \\
(30.49)\end{array}$ & $\begin{array}{c}7.84 \pm 0.13^{* * *} \\
(26.04)\end{array}$ & $\begin{array}{c}7.66 \pm 0.09 * * * \\
(20.44)\end{array}$ \\
\hline $\begin{array}{l}\text { Ct fraction } \\
\text { ( } 200 \mathrm{mg} / \mathrm{kg} \text { body weight })\end{array}$ & $\begin{array}{c}7.26 \pm 0.13 * * * \\
(19.01)\end{array}$ & $\begin{array}{l}7.14 \pm 0.1 \text { ** } \\
\quad(14.79)\end{array}$ & $\begin{array}{l}6.98 \pm 0.07 * \\
\quad(9.74)\end{array}$ \\
\hline $\begin{array}{l}\text { Ct fraction } \\
\text { ( } 400 \mathrm{mg} / \mathrm{kg} \text { body weight })\end{array}$ & $\begin{array}{c}7.94 \pm 0.18 * * * \\
(30.16)\end{array}$ & $\begin{array}{c}7.74 \pm 0.12 * * * \\
(24.43)\end{array}$ & $\begin{array}{c}7.56 \pm 0.1 * * * \\
(18.86)\end{array}$ \\
\hline
\end{tabular}

Note: Each value represents the mean \pm SEM, $(\mathrm{n}=5)$. *** $\mathrm{p}<0.001$, $* * \mathrm{P}<0.01,{ }^{*} \mathrm{p}<0.05$ compared with control (One- way ANOVA followed by Dunnett's test). $\mathrm{Me}=$ Methanol, $\mathrm{PE}=$ Petroleum ether, $\mathrm{EA}=$ Ethyl acetate, $\mathrm{Cl}=$ Chloroform, $\mathrm{Ct}=\mathrm{Carbon}$ tetrachloride .

Table 3. Results of in-vitro anthelmintic activity of methanol extract of $L$. aequata.

\begin{tabular}{lccc}
\hline Test sample & Concentration & \multicolumn{2}{c}{ Time $(\mathrm{min})$} \\
\cline { 3 - 4 } & $(\mathrm{mg} / \mathrm{ml})$ & $\mathrm{P}$ & $\mathrm{D}$ \\
\hline Me Extract & 25 & $15.93 \pm 0.14^{* * *}$ & $18.65 \pm 0.21^{*}$ \\
& 50 & $13.63 \pm 0.1^{* * *}$ & $16.45 \pm .11^{* * *}$ \\
& 100 & $9.44 \pm 0.32^{* * *}$ & $12.9 \pm .31^{* * *}$ \\
Albendazole & 10 & $8.21 \pm 0.17^{* * *}$ & $11.18 \pm .31^{* * *}$ \\
\hline
\end{tabular}

Note: Results are expressed as mean $\pm \operatorname{SEM}(\mathrm{n}=6) .{ }^{*} * * \mathrm{p}<0.001,{ }^{*} \mathrm{p}<0.01, * \mathrm{p}<0.05$ compared to standard (albendazole). Control worms were alive up to $24 \mathrm{hrs}$ of observation. Me=Methanol. 
In case of anthelmintic activity test, the methanol extract (conc. 25 to $100 \mathrm{mg} / \mathrm{ml}$ ) of leaves of $L$. aequata exhibited significant effect on paralyzing the worms, in terms of paralysis time, at every concentration when compared to the standard albendazole (10 mg/ml) (Table 3).

\section{CONCLUSION}

In conclusion, it can be suggested that the methanol extract of leaves of $L$. aequata and its fractions possessed significant antinociceptive properties. The methanol extract also (25 to 100 $\mathrm{mg} / \mathrm{ml}$ ) exhibited significant anthelmintic property. The results suggest the presence of biologically active components in L. aequata which may be worth for further investigation.

\section{REFERENCES}

1. Uddin, S., Shilpi, J., Alam, S., Alamgir, M., Rahman, M. and Sarker, S. 2005. Antidiarrhoeal activity of the methanol extract of the barks of Xylocarpus moluccensis in castor oiland magnesium sulphate-induced diarrhoea models in mice. J. Ethnopharmacol. 101, 139-143.

2. Ahmed, Z.U., Hassan, M.A., Begum, Z.N.T., Khondker, M., Kabir, S.M.H., Ahmed, M., Ahmed, A.T.A., Rahman, A.K.A. and Haque, E.U.(eds.). 2009. Encyclopedia of Flora and Fauna of Bangladesh, Angiosperms: Dicotyledons (Fabaceae-Lythraceae). Asiatic Society of Bangladesh, Dhaka, pp. 40-41.
3. Price, D.D. 2000. Psychological and neural mechanisms of the affective dimension of pain. Science 288, 1769-1772.

4. Nicotine, Merck \& Co. 1996. The Mark Index. 12, 1119: entry 6611 .

5. Dwivedi, A., Dwivedi, S., Sitoke, A.K., Patel, R. and Jhade, D. 2009. Anthelmenthic activity of a polyherbal preparation. Ethnobot Leaflets. 13, 259-262.

6. Jain, S.K., Manikpuri, N., Kujur, M. 2010. Antibacterial activity of seeds, stems and roots of Leea aequata. Biosc. Biotech. Res. Asia. 7, 453-456.

7. Van Wagenen, B.C., Larsen, R., Cardellina, J.H.II, Ran dazzo, D., Lidert, Z.C. and Swithenbank C. 1993. Ulosantoin, a potent insecticide from the sponge Ulosa ruetzleri. J. Org. Chem. 58, 335-337.

8. Koster, R., Anderson, M. and Debeer, E.J. 1959. Acetic acid for analgesic screening. Fed. Proc. 18, 412-417.

9. Vogel, H.G. and Vogel, W.H. 1997. Drug discovery and evaluation: pharmacological assays. New York: SpringerVerlag. 402, 370-371.

10. Ahmed, M., Shikha, H., Sadhu, S., Rahman, M. and Datta, B. 2001. Analgesic, diuretic, and antiinflammatory principle from Scoparia dulcis. Die Pharmazie 56, 657.

11. Ajaiyeoba, E.O., Onocha, P.A. and Olarenwaju, O.T. 2001. In-vitro anthelmentic property of Buchholzia coriaceae and Gynnandropsis gynandra extracts. Pharm. Biol. 56, 657-660. 